\title{
Practice of and Barriers to Prevention by Secondary School Athletic Trainers
}

Caroline C. Guindon

Boston University, cguindon@bu.edu

Zachary K. Winkelmann

Indiana State University, zwinkelmann@sycamores.indstate.edu

Lindsey E. Eberman

Indiana State University, leberman@indstate.edu

Kenneth E. Games

Indiana State University, kenneth.games@indstate.edu

Follow this and additional works at: https://nsuworks.nova.edu/ijahsp

Part of the Community Health and Preventive Medicine Commons, and the Sports Medicine Commons

\section{Recommended Citation}

Guindon CC, Winkelmann ZK, Eberman LE, Games KE. Practice of and Barriers to Prevention by Secondary School Athletic Trainers. The Internet Journal of Allied Health Sciences and Practice. 2018 Jan 01;16(4), Article 4.

This Manuscript is brought to you for free and open access by the College of Health Care Sciences at NSUWorks. It has been accepted for inclusion in Internet Journal of Allied Health Sciences and Practice by an authorized editor of NSUWorks. For more information, please contact nsuworks@nova.edu. 


\title{
Practice of and Barriers to Prevention by Secondary School Athletic Trainers
}

\begin{abstract}
Purpose: Prevention is a key aspect of care from athletic trainers. There is limited research on the practice strategies employed to prevent injury by secondary school athletic trainers (SSATs). The purpose of this study was to describe the prevention practice strategies and barriers faced by secondary school athletic trainers. Methods: Athletic trainers $(n=3010)$ were recruited from secondary schools through emails provided by the national professional organization database. Secondary school athletic trainers were surveyed on their self-reported prevention practices and barriers using a web-based survey platform. Respondents were $28 \pm 3$ years, predominantly female $(n=260 / 359,72.4 \%)$, with about 5 years $( \pm 2 y r s)$ of clinical experience. The survey contained prevention strategies items with tasks from Domain 1 of the Board of Certification Role Delineation Study ( $6^{\text {th }}$ ed.) that relates to athletic training clinical practice. Barrier items were developed from previous literature about implementing evidence-based practice strategies. Partial data (completion rate $=359 / 473,75.9 \%$ ) was used for the analyses. Data were analyzed by using frequencies, medians with percentiles, means, and standard deviations. Results: The least frequently practiced environmental illness monitoring techniques and addressing patient-specific nutritional needs were identified. In contrast, secondary school athletic trainers most frequently practiced compliance for both equipment maintenance and maintaining a clean facility. The most common 'always practiced' skills align with Task 102, 103, and 104 in Domain 1 of the Board of Certification Role Delineation Study. These include pre-participation and screening, personal protective equipment, and maintaining treatment and rehabilitation areas through regulatory standards. A lack of time, workload, player compliance, available space, and coach support were the most commonly cited barriers to prevention practice. Conclusions: Overall, secondary school athletic trainers engaged in prevention strategies frequently, yet external factors were barriers to implementation. The consistent and continual practice of prevention skills are essential to risk mitigation. As a result, always practicing the skill is essential and should not be completed as an occasional duty of the athletic training. As many prevention strategies are required for all patient encounters, the frequency of task performance must improve for clinical practice.
\end{abstract}

\section{Author Bio(s)}

Dr. Caroline Guindon, DAT, LAT, ATC is an Athletic Trainer Resident at Boston University in Orthopedics and Diagnostics, and a graduate of the 2017 Doctorate in Athletic Training program at Indiana State University.

Mr. Zachary Winkelmann, MS, LAT, ATC is a PhD student in Curriculum and Instruction with a concentration in athletic training education at Indiana State University. He is also a certified and licensed athletic trainer.

Dr. Lindsey Eberman, PhD, LAT, ATC is an Associate Professor and Program Director of the Doctorate in Athletic Training program at Indiana State University. In addition, she is a certified and licensed athletic trainer.

Dr. Kenneth Games, DAT, LAT, ATC is an Associate Professor and Director of Clinical Education for the Doctorate in Athletic Training program at Indiana State University. In addition, he serves as the Director of the Neuromechanics, Interventions, and Continuing Education Research (NICER) Laboratory. 


\title{
TIAHSP \\ The Internet Joưnal of Allied Health Sciences and Practice
}

Dedicated to allied health professional practice and education

Vol. 16 No. 4 ISSN 1540-580X

\section{Practice of and Barriers to Prevention by Secondary School Athletic Trainers}

\author{
Caroline C. Guindon, DAT, LAT, ATC1 \\ Zachary K. Winkelmann, MS, LAT, ATC2 \\ Lindsey E. Eberman, PhD, LAT, ATC2 \\ Kenneth E. Games, DAT, LAT, ATC² \\ 1. Boston University \\ 2. Indiana State University \\ United States
}

\begin{abstract}
Purpose: Prevention is a key aspect of care from athletic trainers. There is limited research about the practice strategies employed to prevent injury by secondary school athletic trainers (SSATs). The purpose of this study was to describe the prevention practice strategies and barriers faced by secondary school athletic trainers. Methods: Athletic trainers $(n=3,010)$ were recruited from secondary schools through e-mails provided by the national professional organization database. Secondary school athletic trainers were surveyed for their self-reported prevention practices and barriers using a Web-based survey platform. Respondents were $28 \pm 3$ years old, predominantly female $(n=260 / 359,72.4 \%)$ with about 5 ( \pm 2 yrs) years of clinical experience. The survey contained prevention strategy items with tasks from Domain 1 of the Board of Certification Role Delineation Study $\left(6^{\text {th }}\right.$ ed.) that related to athletic training clinical practice. Barrier items were developed from previous literature about implementing evidence-based practice strategies. Partial data (completion rate $=359 / 473,75.9 \%$ ) were used for the analyses. Data were analyzed by using frequencies, medians with percentiles, means, and standard deviations. Results: The least frequently practiced environmental illness monitoring techniques and patient-specific nutritional needs were identified. In contrast, SSATs most frequently practiced compliance for both equipment maintenance and maintaining a clean facility. The most common "always practiced" skills aligned with Task 102, 103, and 104 in Domain 1 of the Board of Certification Role Delineation Study. These tasks included pre-participation and screening, personal protective equipment, and maintaining treatment and rehabilitation areas through regulatory standards. A lack of time, workload, player compliance, available space, and coach support were the most commonly cited barriers to prevention practice. Conclusions: Overall, SSATs engaged in prevention strategies frequently, yet external factors were barriers to implementation. The consistent and continual practice of prevention skills are essential to risk mitigation. As a result, always practicing the skill is essential and should not be completed as an occasional duty of the athletic trainer. As many prevention strategies are required for all patient encounters, the frequency of task performance must improve for clinical practice.
\end{abstract}

\section{INTRODUCTION}

During the 2015-2016 school year, an injury occurrence rate of 2.32 per 1,000 athlete exposures was identified in United States secondary schools. ${ }^{1}$ Sport injuries are the leading reason for emergency department visits in the adolescent (11 to 18 year old) population and are the leading cause of surgery and missed days of school.2-4 Despite the high risk of injury for secondary school athletics, extrinsic and intrinsic risk factor reduction strategies are effective in preventing sport injuries. ${ }^{2,4,5}$ The practice of risk reduction and prevention is uniquely integrated into secondary school sport through the integration of athletic training services. Previous research for athletic training practice in the secondary school setting indicated that $48.8 \%$ of all patient encounters are related to aspects of prevention. ${ }^{6}$ Additionally, research for the self-reported percentage of daily practice by secondary school athletic trainers (SSATs) indicated that $26.8 \%$ of an average day was focused on the prevention. ${ }^{7}$ This finding demonstrates that SSATs perceive that over a quarter of their day is dedicated to these tasks. The issue that presents with this workload analysis is that the practice of "prevention" may be defined differently from clinician to clinician. 
While the practice of prevention may be occurring, there has been a call for action for athletic trainers to improve the integration of their skills, specifically prevention, within public health. ${ }^{8}$ As a result, athletic trainers should familiarize themselves with the associated tasks related to prevention. The essential knowledge and skills for athletic training professionals are outlined in the Board of Certification Role Delineation Study/Practice Analysis, 6th edition (BOC RDS), and organized into specific domains of practice. One domain of athletic training practice is injury/illness prevention and wellness protection, suggesting that the knowledge and skills to prevent injury are essential to athletic training practice. .,9 $^{2}$ The injury/illness prevention and wellness protection includes 7 tasks of prevention: (BOC RDS Task 101) awareness; education and intervention; (BOC RDS Task 102) interpret preparticipation and screening information; (BOC RDS Task 103) use of personal protective equipment; (BOC RDS Task 104) compliance with regulatory standards of equipment and facilities; (BOC RDS Task 105) monitor environmental conditions and safety; (BOC RDS Task 106) maintain or improve physical conditioning; and (BOC RDS Task 107) promote healthy lifestyle behaviors, such as nutrition, with sub-activities related to each area. ${ }^{10}$

Additionally, athletic trainers should familiarize themselves with the definition of prevention in terms of public health. Prevention has 3 main categories, including primary, secondary, and tertiary prevention practices. There are primary prevention strategies to avoid the onset of an injury or illness, such as educational and informational programming and immunizations. These specific tasks of education and proactive preventative screening are linked to specific BOC RDS domain tasks of awareness and education and interpretation of pre-participation and screening information. The aim of secondary prevention is to reduce the impact of the injury or illness after the detection. In athletic training, secondary prevention measures may include screening for early detection and early intervention or treatment. Previous descriptive research for services provided in the secondary school setting indicated that between $24 \%$ to $49 \%$ of patients sought care for preventative services. ${ }^{6,11}$ Lastly, tertiary prevention helps patient manage and improve the outcomes of long-term injuries and illnesses. These outcomes are accomplished through interventions, which lessen the impact of chronic conditions, such as osteoarthritis, and lessening the long-term effects of concussion. ${ }^{8}$

Within athletic training, injury prevention is often perceived through the idea of intrinsic and extrinsic risk factor identification. For example, a patient is at risk for exertional heat stroke based on his/her age, which is an intrinsic risk factor, and due to the environment, an extrinsic risk factor. In a dynamic injury prevention model, the idea of an at-risk athlete due to intrinsic and extrinsic risk factors does not always equate to the injury or illness presented, which then causes the patient to enter into an adaption and repetition cycle of the event and associated risk factors. ${ }^{12}$ As a result, athletic trainers cannot eliminate all risks of sport participation. ${ }^{12}$ This reason is why the ideas of modifiable and non-modifiable risk factors have emerged in the literature. ${ }^{13}$ With this frame of injury prevention places, the health care provider and patient are placed in the forefront of the implementation process. Factors such as age and sex cannot be modified, yet the use of external support devices, hydration status, and activity site are aspects that can be modified. ${ }^{13}$

Previous researchers have suggested there are barriers to injury prevention implementation, and by understanding potential barriers, there may be an increase in successful implementation of interventions. ${ }^{3,14}$ However, there is limited research about the practice of specific prevention tasks in athletic training, particularly in the secondary school setting. $4,9,10$ The purpose of this study was to determine the self-reported practice frequency and perceived barriers to prevention strategies by athletic trainers in the secondary school setting.

\section{METHODS}

\section{Respondents}

A random sample of e-mail addresses for 3,010 athletic trainers who practice in the secondary school setting was purchased from the National Athletic Trainers' Association (NATA). Four hundred seventy-three respondents accessed the survey for an $11.9 \%$ access rate. Three hundred fifty-nine of the 473 respondents completed a majority (at least $60 \%$ ) of the survey to be included in the analysis (75.9\% completion rate). The complete demographics of the respondents is located in Table 1.

(C) The Internet Journal of Allied Health Sciences and Practice, 2018 
Table 1. Demographic Data of the Respondents and the Secondary School They Predominately Practice Within

\begin{tabular}{|l|c|}
\hline \multicolumn{1}{|c|}{ Variable } & Measures of central tendency \\
\hline Sex $(n=359)$ & $99,27.6 \%$ \\
\hline Male & $260,72.4 \%$ \\
\hline Female & $28 \pm 3$ years \\
\hline Age $(n=341)$ & $5 \pm 2$ years \\
\hline Year of experience $(n=359)$ & $504.9 \pm 362.2$ student-athletes \\
\hline Number of athletes at school $(n=354)$ & $1 \pm 1$ Athletic Trainer \\
\hline Number of athletic trainers at school $(n=359)$ & \\
\hline Budget $(n=359)$ & $42,11.7 \%$ \\
\hline No Budget & $121,33.7 \%$ \\
\hline$\$ 1-2500$ & $102,28.4 \%$ \\
\hline$\$ 2501-5000$ & $53,14.8 \%$ \\
\hline$\$ 5001-10000$ & $24,6.4 \%$ \\
\hline \$10000-15000 & $15,4.2 \%$ \\
\hline Greater than $\$ 15000$ & $2,0.6 \%$ \\
\hline Missing Data & \\
\hline Facility size $(n=359)$ & $8,2.2 \%$ \\
\hline No Dedicated Space & $92,25.6 \%$ \\
\hline Less than 250 ft. ${ }^{2}$ & $139,38.7 \%$ \\
\hline $250-500 \mathrm{ft.}{ }^{2}$ & $86,24.0 \%$ \\
\hline $500-1000 \mathrm{ft.}{ }^{2}$ & $29,8.1 \%$ \\
\hline $1000-2000 \mathrm{ft.}{ }^{2}$ & $3,0.8 \%$ \\
\hline Greater than 2000 ft. ${ }^{2}$ & $2,0.6 \%$ \\
\hline Missing Data & \\
\hline
\end{tabular}

\section{Instrumentation}

A Web-based survey (Qualtrics, Inc., Provo, UT) was developed, consisting of 22 items that included 14 demographic items, 7 self- reported frequency of practice items, and 1 barrier to practice item. The self-reported frequency of practice items was stemmed from the tasks outlined and associated with the injury/illness prevention and wellness protection domain of the BOC RDS. The barrier assessment portion of the questionnaire was modeled after a previous survey, which yielded strong internal consistency (Cronbach's a $=0.8$ ), consistent with the previous study. ${ }^{15}$ Prior to the finalization of the instrument, 3 expert clinicians (combined 60 years of experience in the profession of athletic training) established content validity through a content analysis. The Indiana State University Institutional Review Board deemed this study exempt.

\section{Procedures}

The respondents were invited to complete the survey through e-mail. Reminder e-mails were sent to all potential respondents 2 weeks after the initial invitation to participate. After electronically indicating informed consent, the respondent entered the survey. The respondents were tasked with self-reporting their frequency in which they engaged with each prevention task using a fourpoint Likert scale (always, often, sometimes, never). The respondents were further asked to indicate their level of agreement on a four-point Likert scale (strongly agree, agree, disagree, strongly disagree) from a list of barriers (18 stems) that were associated with implementing prevention (ie, coach support, player compliance, weather, lack of time, etc) in their practice at the secondary school. The data collection period was a total of 3 weeks.

\section{Statistical Analysis}

Data were collected and downloaded into a custom spreadsheet. Partial data were analyzed if the respondent had completed at least $60 \%$ of the instrument. Measures of central tendency were used to provide a summary statistic of all variables of interest and 
reported as percentages and frequencies. All data were analyzed using commercially available statistical analysis software (IBM Corp, IBM SPSS Statistics for Windows, Version 24.0, IBM Inc., Armonk, NY, USA).

\section{RESULTS}

\section{Self-Reported Frequency of Prevention Practice}

Among the most frequently practiced prevention strategies (median $=4$ ) were predominately related to Task 102 and 104: regulatory agencies and pre-participation exams. Specific tasks were included, such as maintaining Occupational Safety and Health Administration (OSHA) compliance (69.1\%), complying with manufacturer recommendations for equipment maintenance $(67.4 \%)$, recognizing malfunction of therapeutic equipment $(63.8 \%)$, collecting pre-participation screening information (61.1\%), and identifying OSHA non-compliance (51.5\%). The least frequently reported strategies were related to wellness protection (Task 107), environmental (Task 105), and personal protective equipment (Task 103). The specific tasks included accessing information concerning accepted guidelines for nutritional practices (12.5\%), fitting protective equipment (10.9\%), utilizing monitoring techniques (10.3\%), and addressing special nutritional needs $(7.8 \%)$. Table 2 presents the frequency of reported prevention practice for all skills in this domain of practice from the BOC RDS.

Table 2. Self-Reported

\begin{tabular}{|c|c|c|c|c|c|c|c|}
\hline Skill & $\begin{array}{c}\text { BOC } \\
\text { Role } \\
\text { Delineation } \\
\text { Study } \\
\text { Associated } \\
\text { Task } \\
\end{array}$ & $\begin{array}{c}\text { Median } \\
\text { (4-point } \\
\text { scale) }\end{array}$ & $\begin{array}{c}\text { Always } \\
\mathrm{N}, \%\end{array}$ & $\begin{array}{l}\text { Often } \\
\mathrm{N}, \%\end{array}$ & $\begin{array}{c}\text { Sometimes } \\
\quad \mathrm{N}, \%\end{array}$ & $\begin{array}{l}\text { Never } \\
\mathrm{N}, \%\end{array}$ & $\begin{array}{c}\text { Missing Data } \\
\quad \mathrm{N}, \%\end{array}$ \\
\hline $\begin{array}{l}\text { Maintain safe and } \\
\text { sanitary environment }\end{array}$ & Task 104 & 4 & $248,69.1 \%$ & $102,28.4 \%$ & $9,2.5 \%$ & $0,0.0 \%$ & $0,0.0 \%$ \\
\hline $\begin{array}{l}\text { Comply with } \\
\text { Manufacturers' } \\
\text { recommendation for } \\
\text { equipment } \\
\text { maintenance } \\
\end{array}$ & Task 103 & 4 & $242,67.4 \%$ & $73,20.3 \%$ & $29,8.1 \%$ & $15,4.2 \%$ & $0,0.0 \%$ \\
\hline $\begin{array}{l}\text { Recognize malfunction } \\
\text { or disrepair of } \\
\text { equipment and facilities }\end{array}$ & Task 104 & 4 & $229,63.8 \%$ & $99,27.6 \%$ & $16,4.5 \%$ & $12,3.3 \%$ & $3,0.8 \%$ \\
\hline $\begin{array}{l}\text { Identify guidelines and } \\
\text { regulations }\end{array}$ & Task 102 & 4 & $228,63.5 \%$ & $109,30.4 \%$ & $18,5.0 \%$ & $4,1.1 \%$ & $0,0.0 \%$ \\
\hline $\begin{array}{l}\text { Apply guidelines and } \\
\text { regulations }\end{array}$ & Task 102 & 4 & $220,61.3 \%$ & $119,33.1 \%$ & $16,4.5 \%$ & $3,0.8 \%$ & $1,0.3 \%$ \\
\hline $\begin{array}{l}\text { Collect } \\
\text { pre-participation } \\
\text { screening information }\end{array}$ & Task 102 & 4 & $219,61.0 \%$ & $71,19.8 \%$ & $38,10.6 \%$ & $30,8.4 \%$ & $1,0.3 \%$ \\
\hline $\begin{array}{l}\text { Recognize } \\
\text { noncompliance with } \\
\text { safety and sanitation } \\
\text { standards }\end{array}$ & Task 104 & 4 & $185,51.5 \%$ & $134,37.3 \%$ & $33,9.2 \%$ & $4,1.1 \%$ & $3,0.8 \%$ \\
\hline $\begin{array}{l}\text { Identify resources for } \\
\text { health care team }\end{array}$ & Task 101 & 3 & $178,49.6 \%$ & $165,46.0 \%$ & $15,4.2 \%$ & $1,0.3 \%$ & $0,0.0 \%$ \\
\hline $\begin{array}{l}\text { Identify disqualifying or } \\
\text { limiting conditions }\end{array}$ & Task 102 & 3 & $175,48.7 \%$ & $124,34.5 \%$ & $51,14.2 \%$ & $9,2.5 \%$ & $0,0.0 \%$ \\
\hline
\end{tabular}




\begin{tabular}{|c|c|c|c|c|c|c|c|}
\hline $\begin{array}{l}\text { Apply } \\
\text { pre-participation } \\
\text { screening information }\end{array}$ & Task 102 & 3 & $173,48.2 \%$ & $116,32.3 \%$ & $42,11.7 \%$ & $28,7.8 \%$ & $0,0.0 \%$ \\
\hline $\begin{array}{l}\text { Identify resources for } \\
\text { screening }\end{array}$ & Task 102 & 3 & $171,47.6 \%$ & $172,47.9 \%$ & $15,4.2 \%$ & $1,0.3 \%$ & $0,0.0 \%$ \\
\hline $\begin{array}{l}\text { Conduct inspections } \\
\text { and recognize hazards }\end{array}$ & Task 105 & 3 & $169,47.1 \%$ & $150,41.8 \%$ & $33,9.2 \%$ & $6,1.7 \%$ & $1,0.3 \%$ \\
\hline Risk identification & Task 101 & 3 & $149,41.5 \%$ & $182,50.7 \%$ & $28,7.8 \%$ & $0,0.0 \%$ & $0,0.0 \%$ \\
\hline Communication & Task 101 & 3 & $133,37.0 \%$ & $217,60.4 \%$ & $9,2.5 \%$ & $0,0.0 \%$ & $0,0.0 \%$ \\
\hline $\begin{array}{l}\text { Identify conditions } \\
\text { requiring commercially } \\
\text { available and/or } \\
\text { custom-made devices }\end{array}$ & Task 103 & 3 & $126,35.1 \%$ & $165,46.0 \%$ & $60,16.7 \%$ & $7,1.9 \%$ & $1,0.3 \%$ \\
\hline $\begin{array}{l}\text { Gather/interpret } \\
\text { information regarding } \\
\text { environmental data }\end{array}$ & Task 105 & 3 & $116,32.3 \%$ & $155,43.2 \%$ & $78,21.7 \%$ & $10,2.8 \%$ & $0,0.0 \%$ \\
\hline $\begin{array}{l}\text { Recognize } \\
\text { environmental and } \\
\text { ergonomic risks } \\
\end{array}$ & Task 105 & 3 & $113,31.5 \%$ & $178,49.6 \%$ & $65,18.1 \%$ & $2,0.6 \%$ & $1,0.3 \%$ \\
\hline \begin{tabular}{|l|} 
Correct or modify \\
inappropriate, unsafe, or \\
dangerous activities
\end{tabular} & Task 106 & 3 & $112,31.2 \%$ & $131,36.5 \%$ & $92,25.6 \%$ & $15,4.2 \%$ & $9,2.5 \%$ \\
\hline \begin{tabular}{|l|} 
Communicate with \\
appropriate \\
professionals regarding \\
referral
\end{tabular} & Task 107 & 3 & $107,29.8 \%$ & $121,33.7 \%$ & $103,28.7 \%$ & $16,4.5 \%$ & $12,3.3 \%$ \\
\hline \begin{tabular}{|l|} 
Recommend and \\
implement appropriate \\
methods for addressing \\
environmental and \\
individual risks
\end{tabular} & Task 105 & 3 & $94,26.2 \%$ & $196,54.6 \%$ & $65,18.1 \%$ & $3,0.8 \%$ & $1,0.3 \%$ \\
\hline $\begin{array}{l}\text { Instruct in the use of } \\
\text { appropriate conditioning } \\
\text { equipment }\end{array}$ & Task 106 & 3 & $93,25.9 \%$ & $125,34.8 \%$ & $111,30.9 \%$ & $21,5.8 \%$ & $9,2.5 \%$ \\
\hline
\end{tabular}




\begin{tabular}{|c|c|c|c|c|c|c|c|}
\hline $\begin{array}{l}\text { Educate patients on } \\
\text { protective equipment }\end{array}$ & Task 103 & 3 & $90,25.1 \%$ & $163,45.4 \%$ & $92,25.6 \%$ & $14,3.9 \%$ & $0,0.0 \%$ \\
\hline $\begin{array}{l}\text { Educate appropriate } \\
\text { individuals in the } \\
\text { effective application of } \\
\text { conditioning programs }\end{array}$ & Task 106 & 3 & $82,22.8 \%$ & $137,38.2 \%$ & $113,31.5 \%$ & $19,5.4 \%$ & $8,2.2 \%$ \\
\hline \begin{tabular}{|l|} 
Address components of \\
a comprehensive \\
conditioning program
\end{tabular} & Task 106 & 3 & $78,21.7 \%$ & $141,39.3 \%$ & $110,30.6 \%$ & $22,6.1 \%$ & $8,2.2 \%$ \\
\hline $\begin{array}{l}\text { Recognize } \\
\text { characteristics of } \\
\text { participants } \\
\text { predisposing them to } \\
\text { environmental and } \\
\text { ergonomic risks } \\
\end{array}$ & Task 105 & 3 & $77,21.4 \%$ & $189,52.6 \%$ & $90,25.1 \%$ & $2,0.6 \%$ & $1,0.3 \%$ \\
\hline $\begin{array}{l}\text { Assess appropriateness } \\
\text { of individual or group } \\
\text { participation in } \\
\text { conditioning programs }\end{array}$ & Task 106 & 3 & $67,18.7 \%$ & $129,35.9 \%$ & $124,34.5 \%$ & $31,8.6 \%$ & $8,2.2 \%$ \\
\hline $\begin{array}{l}\text { Interpreting rules about } \\
\text { protective equipment }\end{array}$ & Task 103 & 3 & $63,17.5 \%$ & $134,37.3 \%$ & $132,36.8 \%$ & $30,8.4 \%$ & $0,0.0 \%$ \\
\hline $\begin{array}{l}\text { Select and apply } \\
\text { commercial devices }\end{array}$ & Task 103 & 3 & $60,16.7 \%$ & $142,39.6 \%$ & $136,37.9 \%$ & $21,5.8 \%$ & $0,0.0 \%$ \\
\hline \begin{tabular}{|l|} 
Recognize signs and \\
symptoms of nutritional, \\
addiction, and stress \\
related disorders \\
\end{tabular} & Task 107 & 3 & $58,16.2 \%$ & $148,41.2 \%$ & $133,37.0 \%$ & $9,2.5 \%$ & $11,3.1 \%$ \\
\hline \begin{tabular}{|l|} 
Access information for \\
nutritional practices
\end{tabular} & Task 107 & 2 & $45,12.5 \%$ & $122,34.0 \%$ & $156,43.5 \%$ & $25,7.0 \%$ & $11,3.1 \%$ \\
\hline $\begin{array}{l}\text { Fit protective } \\
\text { equipment }\end{array}$ & Task 103 & 2 & $39,10.9 \%$ & $101,28.1 \%$ & $172,47.9 \%$ & $47,13.1 \%$ & $0,0.0 \%$ \\
\hline $\begin{array}{l}\text { Utilize physiological } \\
\text { monitoring techniques }\end{array}$ & Task 105 & 2 & $37,10.3 \%$ & $83,23.1 \%$ & $170,47.4 \%$ & $69,19.2 \%$ & $0,0.0 \%$ \\
\hline $\begin{array}{l}\text { Address special } \\
\text { nutritional needs }\end{array}$ & Task 107 & 2 & $28,7.8 \%$ & $127,35.4 \%$ & $169,47.1 \%$ & $24,6.7 \%$ & $11,3.1 \%$ \\
\hline
\end{tabular}

\section{( $\mathrm{n}=359$ ). 4 = Always, 3 = Often, 2 = Sometimes, 1 = Never}

\section{Barriers to Prevention Practice}

The most commonly cited barriers were a lack of time, workload, player compliance, available space, coach support, and budget. The majority of respondents $(n=281 / 359,78.2 \%)$ agreed to some extent that time was a barrier to utilizing prevention strategies. Contrastingly, respondents disagreed that a lack of preparedness $(n=234 / 359,65.1 \%)$ or a lack of guidance $(n=222 / 359,61.8 \%)$ were barriers to utilizing prevention techniques. Three quarters of respondents $(n=274 / 359,76.3 \%)$ disagreed to some extent that prevention practices were not necessary in the secondary school athletic training setting. The complete barrier agreement data is in Table 3. 
Table 3. Level of Agreement with Barriers to Injury Prevention Strategies

\begin{tabular}{|l|c|c|c|c|c|c|}
\hline \multicolumn{1}{|c|}{ Barrier } & $\begin{array}{c}\text { Median } \\
\text { (four-point } \\
\text { scale) }\end{array}$ & $\begin{array}{c}\text { Strongly } \\
\text { agree } \\
\mathbf{N}, \%\end{array}$ & $\begin{array}{c}\text { Agree } \\
\mathbf{N}, \%\end{array}$ & $\begin{array}{c}\text { Disagree } \\
\mathbf{N}, \%\end{array}$ & $\begin{array}{c}\text { Strongly } \\
\text { disagree } \\
\mathbf{N}, \%\end{array}$ & $\begin{array}{c}\text { Missin } \\
\mathbf{g} \text { data } \\
\mathbf{N}, \%\end{array}$ \\
\hline Lack of time & 3 & $125,34.8 \%$ & $156,43.5 \%$ & $45,12.5 \%$ & $9,2.5 \%$ & $24,6.7 \%$ \\
\hline Workload & 3 & $98,27.3 \%$ & $167,46.5 \%$ & $58,16.2 \%$ & $8,2.2 \%$ & $28,7.8 \%$ \\
\hline Player compliance & 3 & $88,24.5 \%$ & $193,53.8 \%$ & $48,13.4 \%$ & $6,1.9 \%$ & $24,6.7 \%$ \\
\hline Available space & 3 & $84,23.4 \%$ & $136,37.9 \%$ & $91,25.3 \%$ & $21,5.8 \%$ & $27,7.5 \%$ \\
\hline Coach support & 3 & $82,22.8 \%$ & $154,42.9 \%$ & $72,20.1 \%$ & $27,7.5 \%$ & $24,6.7 \%$ \\
\hline Budget & 3 & $62,17.3 \%$ & $139,38.7 \%$ & $100,27.9 \%$ & $32,8.9 \%$ & $26,7.2 \%$ \\
\hline $\begin{array}{l}\text { Effort required of } \\
\text { intervention }\end{array}$ & 3 & $23,6.4 \%$ & $148,41.2 \%$ & $147,40.9 \%$ & $14,3.9 \%$ & $27,7.5 \%$ \\
\hline Intervention fidelity & 3 & $12,3.3 \%$ & $196,54.6 \%$ & $110,30.6 \%$ & $7,1.9 \%$ & $34,9.5 \%$ \\
\hline $\begin{array}{l}\text { Lack of administrative } \\
\text { support }\end{array}$ & 2 & $41,11.4 \%$ & $99,27.6 \%$ & $138,38.4 \%$ & $55,15.3 \%$ & $26,7.2 \%$ \\
\hline Knowledge level & 2 & $29,8.1 \%$ & $93,25.9 \%$ & $156,43.5 \%$ & $56,15.6 \%$ & $25,7.0 \%$ \\
\hline Weather & 2 & $23,6.4 \%$ & $112,31.2 \%$ & $140,39.0 \%$ & $57,15.9 \%$ & $27,7.5 \%$ \\
\hline $\begin{array}{l}\text { Relevance to patient } \\
\text { population }\end{array}$ & 2 & $18,5.0 \%$ & $124,34.5 \%$ & $166,46.2 \%$ & $24,6.7 \%$ & $27,7.5 \%$ \\
\hline $\begin{array}{l}\text { Difficulty for patient to } \\
\text { complete }\end{array}$ & 2 & $18,5.0 \%$ & $111,30.9 \%$ & $178,49.6 \%$ & $25,7.0 \%$ & $27,7.5 \%$ \\
\hline Lack of guidance & 2 & $17,4.7 \%$ & $94,26.2 \%$ & $179,49.9 \%$ & $43,12 \%$ & $28,7.8 \%$ \\
\hline $\begin{array}{l}\text { Lack of preparedness } \\
\text { Analysis and }\end{array}$ & 2 & $11,3.1 \%$ & $88,24.5 \%$ & $177,49.3 \%$ & $57,15.9 \%$ & $26.7 .2 \%$ \\
\hline scoring & 2 & $10,2.8 \%$ & $99,27.6 \%$ & $184,51.3 \%$ & $37,10.3 \%$ & $29,8.1 \%$ \\
\hline $\begin{array}{l}\text { Anxiety level of patient } \\
\text { practices are not } \\
\text { necessary }\end{array}$ & 2 & $9,2.5 \%$ & $110,30.6 \%$ & $172,47.9 \%$ & $42,11.7 \%$ & $26,7.2 \%$ \\
\hline Discussion & $3,0.8 \%$ & $11,3.1 \%$ & $71,19.8 \%$ & $247,68.8 \%$ & $27,7.5 \%$ \\
\hline & & & & & & \\
\hline
\end{tabular}

\section{DISCUSSION}

The self-reported practices of and barriers to prevention by athletic trainers in the secondary school setting were explored in this study. Respondents indicated they engaged in prevention strategies frequently. While previous researchers reported that SSATs are involved with many prevention-based patient encounters, $24 \%$ of the respondents in this sample perceived that injury/illness prevention was unnecessary. ${ }^{6}$ This finding is of concern as prevention is one of the characteristics of the AT profession and our role as part of the athletic care network alongside the directing physician and other health care providers. Despite these findings, many of the prevention strategies are federal regulations and should have near $100 \%$ compliance in clinical practice.

\section{Prevention Practice}

As stated in Task 101 of the BOC RDS, athletic trainers should "minimize risk of injury and illness of individuals and groups impacted by or involved in a specific activity through awareness, education and intervention."10 The respondents in our sample reported between $37 \%$ to $50 \%$ always performing the associated skills, including communicating effectively, identifying appropriate resources, and identifying risks. The practice of the skills associated with Task 101 is supported in the literature. As athletic trainers in the secondary school setting, previous researchers have identified that a lack of awareness was a common reason for not 
reporting a concussion. ${ }^{16}$ Additionally, the study had a call for future educational interventions to improve the athlete's understanding of concussions. ${ }^{16}$ As athletic trainers, education is an imperative skill related to prevention practice. Specifically, sudden death prevention is commonly associated with education and awareness interventions. ${ }^{17}$ The recommendations in the NATA position statement about prevention of sudden death were that a priority for prevention should be education, specifically for head-down contact and brain injury. ${ }^{17}$ Additionally, the NATA position statement about injuries due to overuse in the pediatric population indicated that overuse injuries may be reduced through proper education of student-athlete patients, parents, coaches, and officials regarding risks. ${ }^{18}$ For example, the USA Football Heads-Up and the American Sports Education program present online and traditional sessions to reduce the knowledge gap regarding first aid, environmental hazards, and safe tackling. ${ }^{18}$ Finally, patients with conditions that make them susceptible to injury and illness should be identified. For example, sickle cell disease should be screened for to provide tailored education for each patient. ${ }^{19}$ The identification of this condition, much like that of underlying cardiac abnormalities, should be considered from an identification of risk rather than the screening itself, which means that SSATs should be able to identify resources available to recognize and refer individuals with cardiovascular and environmental risks. ${ }^{17}$ We would encourage SSATs to consider coordinating and hosting educational sessions for stakeholders, such as parents and coaches, to improve this prevention task.

The ability to "interpret individual and group pre-participation and other relevant screening information (e.g., verbal, observed, written) in accordance with accepted and applicable guidelines to minimize the risk of injury and illness" is associated with Task 102 of the BOC RDS. ${ }^{10}$ The skills associated with this task that were most frequently "always" practiced included collecting preparticipation screening information and identifying and applying guidelines and regulations; however, these skills ranged in frequency between $61 \%$ to $63 \%$ of consistent practice. The other skills associated with this task were categorized as often practiced by SSATs and included aspects, such as applying pre-participation screening information; identifying conditions that limit or compromise participation; and identifying appropriate resources, which ranged in frequency between $47 \%$ to $49 \%$ of consistent practice. The process of planning, performing, and interpreting pre-participation physical examinations is a skill crucial to prevention. In the secondary school setting, this skill is even more vital as the competition level and development stage of the body are both changing. Previous researchers have identified the need for pre-participation exams to determine readiness to participate..$^{20}$ The aspects of a pre-participation exam should be inclusive of all aspects of the student-athlete patient, including an orthopedic examination, such as the 90-second musculoskeletal screening examination, and special medical tests, including dental, vision (Snellen eye exam), cardiovascular (family and medical history and physical examination, which may include a 12lead EKG), neurologic, and general medical screening (blood panel for sickle cell trait, ferritin, and vitamin $D$ levels). ${ }^{17,20,21}$ In addition, aspects of the pre-participation exam should be able to measure physical fitness and mental health, include injury risk factor screening, and have an abdominal/genital palpation exam. ${ }^{18,21}$ The act of purely completing a comprehensive physical examination is not sufficient for pre-participation. Following the completion of a pre-participation exam, the SSATs in consultation with their supervising physician, should apply the relevant screening information through several means, including further evaluation, corrective therapeutic interventions, and lifestyle modifications. ${ }^{18,20}$ The practice of these skills is essential to identify risk factors that may predispose an athlete to a serious injury or illness, including sudden death. As a result, the frequency of these practices should be always accomplished as a means of personal risk mitigation. In case law relevant to athletic training, Rouse $v$. South Carolina Board of Education, Darlington School County Board, Hartsville High School, South Carolina High School League, Lake Robinson Rescue Squad, Darlington County Emergency Preparedness, and Darlington County stated that during a high school physical examination, the physician cleared a student athlete and marked on the form all aspects of the exam were normal. ${ }^{22}$ Yet upon closer inspection, the patient had a high blood pressure reading (154/74) that was circled on the form, denoting some concern for this measure. ${ }^{22}$ Neither the patient nor the parents of the minor were notified of the measurement, and no subsequent follow-up visits were ever suggested for further evaluation. ${ }^{22}$ The patient subsequently passed out during a workout 3 months later and collapsed again during a football game. ${ }^{22}$ The patient died from hypertrophic cardiomyopathy. ${ }^{22}$ The lawsuit indicated that the physical examination lacked diligence and accuracy to ensure the patient's health was at the forefront of the visit. This case shows the need for focused, individualized pre-participation exams for student athletes. SSATs should take time the time to collect and apply appropriate screening information for completed physical exams even though a physician may have cleared the student athlete for participation.

The skills in Task 103, which are the identification and education of individual(s) and groups through appropriate communication methods (eg, verbal and written) about the appropriate use of personal protective equipment by following accepted procedures and guidelines, have mixed responses from this sample of SSATs. ${ }^{10}$ When examining the always-practiced responses, the skill of complying with manufacturer's recommendation for maintenance of equipment was noted by $67.4 \%$ of respondents, making it the second highest overall practiced skill. In contrast, the other skills associated with this task ranged between $10 \%$ to $35 \%$ of consistent practice with most respondents noting often practicing the skill yet few always practicing. These skills are often associated with protective equipment, including shoes, shoulder pads, helmets, and braces. When examining previous literature about the importance of this skill, we were able to identify that annual reconditioning of football helmet screws had a more favorable

(C) The Internet Journal of Allied Health Sciences and Practice, 2018 
success of removal. ${ }^{23}$ This skill is crucial in the act of spine boarding an equipment-laden athlete. While some SSATs may not perceive this specific skill as part of their job-related duties, we believe it is necessary for interprofessional communication between equipment managers and the athletic care network to ensure these practices are occurring on a regular basis. In order to practice evidence-based prevention, SSATs should be familiar with the literature about this topic, which indicates that there is no strong relationship between shoe type and ankle sprains. ${ }^{24}$ On the same note, increased mileage on a running shoe may increase the risk for a patient to develop lower leg pain, including medial tibial stress syndrome..$^{25}$ As a result, the choice of clothing and shoes should be a skill athletic trainers are familiar with to educate patients about for their personal selection.

Task 104 outlines the skills associated with "maintaining a physical activity, clinical treatment, and rehabilitation areas by complying with regulatory standards to minimize the risk of injury and illness."10 Typically, these are federal guidelines established by OSHA. Some OSHA standards that directly affect athletic training facilities include having food/beverage in treatment areas, having a hand-washing station, and establishing an exposure-control plan. ${ }^{26}$ Additionally, SSATs should ensure their athletic training facility has sharps containers and biohazard bags, personal protective equipment such as gloves, and documented decontamination procedures of work surfaces. ${ }^{26}$ Two of the skills associated with Task 104 (maintain safe and sanitary environment and recognize malfunction of modalities) were ranked as the number 1 and 3 most frequently practiced skills. ${ }^{10}$ The ability to recognize noncompliance with safety and sanitization standards was less frequently practiced with just over $50 \%$ of all respondents always practicing this skill. In the literature, the skills associated with this task are not as practiced as well as some athletic trainers may perceive. Previous research about secondary schools indicated that between $90 \%$ to $100 \%$ of all facilities tested (athletic training facility, athletic locker room, and wrestling mats) had a positive methicillin-resistant Staphylococcus aureus (MRSA) sample.27,28 This finding indicates the need for $100 \%$ compliance of these strategies in clinical practice to prevent the spread of disease.

SSATs should consider the skills associated with Task 105 essential to prevention. The task indicates that athletic trainers should "monitor environmental conditions (e.g., weather, surfaces, client work-setting) using appropriate methods and guidelines to facilitate individual and group safety". ${ }^{10}$ Environmental conditions commonly associated with sport participation include exertional heat illness, hyponatremia, and lightning strikes. In order for prevention of these conditions, SSATs should consider conduct inspections; recognize hazards; use monitoring techniques; recognize environmental risks, including characteristics that predispose an individual; and recommend risk methods using available resources. The practice of these skills from our sample of SSATs varied between $10 \%$ to $47 \%$ with the use of monitoring techniques, such as weight charts and fluid intake, being a skill only sometimes practiced in this setting. This finding is similar to previous exertional heat illness findings in which most SSATs did not implement and comply with all of the necessary prevention strategies and guidelines during preseason football. ${ }^{29}$ SSATs should complete facility safety checks prior to events; monitor local weather, including air quality, severe weather storms, and relative humidity; and complete weight charts during preseason sport acclimation. The skills associated with these prevention strategies should be promoted as the links of death due to environmental conditions have been identified in the literature, thus creating a priority for implementation. ${ }^{17}$

The sample of SSATs in this study reported often utilizing the skills of Task 106: maintaining and improving physical conditioning for the individual or group by designing and implementing programs (eg, strength, flexibility, and cardiovascular fitness) to minimize the risk of injury and illness. ${ }^{10}$ Overall, the tasks were always performed between $18 \%$ to $31 \%$ of the time, depending on the skill. Typically, this specific task is the one that many athletic trainers associate prevention strategies with in clinical practice. Several injury-prevention programs exist. The risk reduction following the injury-prevention program in the secondary school setting for athletes demonstrates the effectiveness of the time associated with the task. ${ }^{30}$ Additionally, the recommendations of the NATA position statement indicate that pediatric athletes engage in preseason and in-season prevention activities to reduce the risk of injuries due to overuse. ${ }^{18}$ We recommend to SSATs to educate parents, coaches, and student athletes about the injury-prevention programs to encourage home-based injury-prevention programs if barriers to implementation include workload and time as this method has demonstrated effectiveness in secondary-school-aged individuals. ${ }^{5}$

Finally, Task 107 states, "athletic trainers should promote healthy lifestyle behaviors using appropriate education and communication strategies to enhance wellness and minimize the risk of injury and illness." 10 In our study, the practice of this task differed between often and sometimes practiced with a range of "always" skill frequency between $7.8 \%$ to $29.8 \%$. This finding is of concern as the skills associated with this task include nutritional needs; communication with appropriate professionals for referral and treatment; and recognition of the signs of nutritional, stress, and addiction-related disorders. As mental health emergencies emerge to the forefront of athletic training, we suggest athletic trainers familiarize themselves with these conditions and disorders to be able to recognize and refer when appropriate. The lack of skill frequency may be due to lack of knowledge about the topic. Previous researchers have identified that athletic trainers in the college and university setting have appropriate knowledge of nutrition yet should refer student athletes to a dietician when unfamiliar situations arise. ${ }^{31}$ Previous researchers have also identified that student athletes do not adequately eat prior to, during, and after exercise. ${ }^{32}$ As a result, SSATs have a duty to address the

(C) The Internet Journal of Allied Health Sciences and Practice, 2018 
nutritional needs of sport, including education of energy drinks, proper carbohydrate intake, and dietary modifications for injury prevention. Overall, this category of injury prevention deserves attention as the skill frequency for this category was the lowest as compared with the other tasks in the BOC RDS.

\section{Barriers to Practice}

Athletic trainers identified several external barriers to their practice. External barriers are something or someone in the environment that inhibits the practice, whereas internal barriers are personal factors that can be regulated or changed within oneself. The most common barriers identified in our study were a lack of time, workload, player compliance, available space, coach support, and budget. In previous literature about health care prevention practice, similar barriers, including time, workload, coach support, and player compliance with successful implementation were identified. 3,14,15,33 Additionally, an increased number of perceived barriers can lead to a decrease in practice of preventative strategies. ${ }^{33}$ In order for prevention practice to be effectively introduced into the SSAT, previous researchers supported that planning and preparation is necessary for prevention practices. ${ }^{34,35}$ Preparation includes the creation and implementation of policy and procedures relevant to prevention tasks, specifically those outlined in the practice section of this discussion.

The most common barrier acknowledged from this sample of SSATs was a lack of time. This barrier is a common one in athletic training practice. Previous researchers have identified that time is a barrier to implementation of patient-reported outcomes, which may be used preventively to screen student athletes. ${ }^{36}$ In addition, current athletic training services in this setting are limited with only $37 \%$ of US secondary schools having full-time services in the school. ${ }^{37}$ As a result, some SSATs may want to practice preventative strategies more often, yet the hiring practice of the secondary school has limited their ability. In order to improve prevention practice, we suggest that additional athletic trainers be hired per school, or increase the athletic trainer from part-time and per diem status to full-time status. We believe this shift in hiring practice will improve frequency of prevention practice. In secondary schools in which one athletic trainer was employed, the trainer reported that he/she spent more of the daily workload on injury and illness prevention as compared with schools with two athletic trainers. ${ }^{7}$ The hiring of another athletic trainer may alleviate the role strain for one athletic trainer to complete all of the associated tasks with prevention outlined in the BOC RDS.

The workload barrier is often associated with role strain and role commitment from the athletic training position in the secondary school setting. SSATs stated they felt they have a professional responsibility to injured athletes. ${ }^{38}$ As a result, the practice of injury prevention may be overlooked as a necessary component of professional practice in the secondary school setting because of the respect and rewards that are associated with injury and return to activity for student athletes. ${ }^{38}$ Previous researchers who studied the characteristics of SSATs identified that they worked around ${ }^{46}$ hours per week (with an 18-hour standard deviation, meaning the range could be between 28 and 64 hours per week). ${ }^{7}$ When exploring the epidemiology of non-time loss injuries, SSATs have a large workload burden.39 Secondary school athletes have 1.6 times greater proportion of non-time loss injuries reported in injury surveillance data. ${ }^{39}$ This finding means that SSATs have to treat and manage more non-time loss injuries, which are defined as injuries resulting in a sport restriction of less than 24 hours. ${ }^{39}$ As a result, the SSAT workload from being predominately part-time, a feeling of a role commitment to the injured athlete, and a burden of non-time loss injuries may affect the burden of workload has on prevention practice.

The external barriers of player compliance and coach support were noted frequently by the SSATs in this sample. While these factors may be perceived as a barrier, many of the skills associated the BOC RDS prevention tasks include educating stakeholders, such as student athletes, parents, coaches, administrators, and officials. Educational sessions about prevention practice should include a time for questions and answers to promote buy-in from coaches. As SSATs seek to improve prevention practice, the need to educate coaches about prevention tasks and programs is essential. Previous researchers identified that advantages, compatibility, and complexity of the injury prevention program are topics of interest when providing education to coaches to improve frequency of practice. ${ }^{40}$

Addition external barriers associated with prevention practice are the available space and budget. The available space to perform associated tasks are commonly associated with the lack of space in athletic training facilities in the secondary school. In this study, $25.6 \%(n=92)$ of respondents stated they provided care in a facility of 250 square feet or less with an additional $38.7 \%(n=139)$ working in an athletic training facility of 250 to 500 square feet. Using best practice guidelines for facility size, an athletic training facility should have a minimum size of 300 square feet, and new facility size should be determined by calculating the number of patients at peak of care divided by 20 patients per table per day times 100 square feet. If we used the average descriptive data and assumed $48 \%$ of patient encounters are for prevention, we could assume if our average number of athletes was 504, then 241 patients may seek prevention at the peak of care. This number divided by 20 and multiplied by 100 would elicit a facility size of approximately 1,205 square feet. While this situation is hypothetical and may not be applicable to all secondary schools, SSATs should advocate for more space to improve prevention practices to reduce the associated risk of injury from sport participation.

(C) The Internet Journal of Allied Health Sciences and Practice, 2018 
Finally, the aspect of budget is a common barrier to many associated tasks across professions. Previous researchers have identified that most secondary schools have an annual supply budget under $\$ 3500$ to $\$ 4000.7,41$ This figure is of interest as a budget is a modifiable external barrier that can greatly affect the care and services provided. ${ }^{11}$ In contrast, SSATs with a smaller supply budget typically spend most of their daily workload on prevention. ${ }^{7}$ While this finding may be true, we believe a low budget may be linked to practice frequency of some skills that require supplies, such as fitting protective equipment and using monitoring techniques. While unable to discern from this sample, the frequency of practice for these tasks may be linked to a low budget for supplies to monitor and assess for secondary school student-athlete patients.

\section{Limitations}

This study suffered from threats to both internal and external validity. In terms of internal validity, this study had the AT self-report frequency of skill use. This retrospective analysis of daily practice may not be reflective of the current daily practice due to a selfperception issue. Additionally, a threat to external validity occurred from a struggle to achieve a large sample. This threat may have been due to the timing of study distribution (late April when secondary schools are approaching the end of the academic year) and length of our data collection window. However, the response rate is consistent with recent studies published in the field. Future research should focus on SSATs knowledge of prevention strategies, SSATs observed practice habits, and how to decrease the impact barriers have on prevention skill implementation.

\section{CONCLUSION}

Overall, the frequency of prevention practice by SSATs often occurred with some skills always occurring. Despite this finding, none of the associated skills and tasks had 100\% practice adherence. As a result, the lack of attention to these skills warrants further investigation as a risk identification and injury prevention are associated with a reduction of sudden death and improved long-term patient outcomes. The barriers to prevention practice, including coaches and players, available space and budget, and time and workload, must be addressed. Each of these groups has an implicit ability for change through education to stakeholders, allocation of resources from the hiring agency and secondary school, and improvement of personal daily practice strategies and hiring of additional staff members. This study will aid SSATs' understanding of the associated tasks with prevention and highlight areas in which they may be able to improve their own clinical practice as a result of this study. The results from this study will also aid SSATs in discussing the need for allocation of resources to improve prevention practice strategies.

\section{REFERENCES}

1. Comstock R, Currie D, Pierpoint L. National High School Sports-Related Injury Surveillance Study: 2015-2016 Colorado School of Public Health; 2016.

2. Rössler R, Donath L, Verhagen E, Junge A, Schweizer T, Faude O. Exercise-based injury prevention in child and adolescent sport: a systematic review and meta-analysis. Sports Med. 2014;44(12):1733-48. [PMID: 25129698]

3. Emery CA, Hagel B, Morrongiello BA. Injury Prevention in Child and Adolescent Sport: Whose Responsibility Is It? Clin J Sport Med. 2006;16(6):514-21. [PMID: 17119364]

4. McGuine T. Sports Injuries in High School Athletes: A Review of Injury-Risk and Injury-Prevention Research. Clin J Sport Med. 2006;16(6):488-99. [PMID: 17119362]

5. Emery CA, Cassidy JD, Klassen TP, Rosychuk RJ, Rowe BH. Effectiveness of a home-based balance-training program in reducing sports-related injuries among healthy adolescents: a cluster randomized controlled trial. CMAJ. 2005;172(6):749-54. [PMID: 15767608]

6. Lam KC, Valier ARS, Anderson BE, McLeod TCV. Athletic training services during daily patient encounters: a report from the Athletic Training Practice-Based Research Network. J Athl Train. 2016;51(6):435-41. [PMID:27315222]

7. Winkelmann ZK, Eberman LE. Characteristics of secondary school athletic trainers: Salary, job satisfaction, and perceived percentage of daily practice. Athl Train Sports Health Care. 2017;9(3):124-32.

8. Hoffman M, Bovbjerg V, Hannigan K, Hootman JM, Johnson ST, et al. Athletic training and public health summit. J Athl Train. 2016;51(7):576-80. [PMID: 27295487]

9. National Athletic Trainers' Association. Athletic Training Education Competencies. 2011. Available from: https://www.nata.org/sites/default/files/competencies_5th_edition.pdf.

10. Board of Certification,2010. The 2009 Athletic Trainer Role Deliniation Study. Omaha, NE: Stephen B. Johnson.

11. McLeod TCV, Lam KC, Bay RC, Sauers EL, Valier ARS. Practice-Based Research Networks, Part II: A Descriptive Analysis of the Athletic Training Practice-Based Research Network in the Secondary School Setting. J Athl Train. 2012;47(5):557-66. [PMID: 23068594]

12. Meeuwisse WH, Tyreman H, Hagel B, Emery C. A dynamic model of etiology in sport injury: the recursive nature of risk and causation. Clin J Sport Med. 2007;17(3):215-9. [PMID: 17513916] 
13. Cameron KL. Commentary: Time for a paradigm shift in conceptualizing risk factors in sports injury research. $J$ Athl Train. 2010;45(1):58-60. [PMID: 20064049]

14. Twomey DM, Doyle TLA, Lloyd DG, Elliot BC, Finch CF. Challenges when implementing an evidence-based exercise injury prevention training program in community-level sport. J Applied Case Studies in Sport and Exercise Science. 2015;1(1).

15. Luquis RR, Paz HL. Attitudes About and Practices of Health Promotion and Prevention Among Primary Care Providers. Health Promot Pract. 2014:745-55. [PMID: 25445979]

16. McCrea M, Hammeke T, Olsen G, Leo P, Guskiewicz K. Unreported concussion in high school football players: implications for prevention. Clin J Sport Med. 2004;14(1):13-7. [PMID: 14712161]

17. Casa DJ, Guskiewicz KM, Anderson SA, Courson RW, Heck JF, et al. National Athletic Trainers' Association position statement: preventing sudden death in sports. J Athl Train. 2012;47(1):96-118. [PMID: 22488236]

18. Valovich McLeod TC, Decoster LC, Loud KJ, Micheli LJ, Parker JT, et al. National Athletic Trainers' Association position statement: prevention of pediatric overuse injuries. J Athl Train. 2011;46(2):206-20. [PMID: 21391806]

19. National Athletic Trainers' Association. Consensus Statement: sickle cell trait and the athlete. 2013. Available from: https://www.nata.org/sites/defaultffiles/SickleCellTraitAndTheAthlete.pdf.

20. Casa DJ, Almquist J, Anderson SA, Baker L, Bergeron MF, et al. The inter-association task force for preventing sudden death in secondary school athletics programs: best-practices recommendations. J Athl Train. 2013;48(4):546- 53. [PMID: 23742253]

21. Conley KM, Bolin DJ, Carek PJ, Konin JG, Neal TL, Violette D. National Athletic Trainers' Association position statement: preparticipation physical examinations and disqualifying conditions. J Athl Train. 2014;49(1):102-20. [PMID: 24499039]

22. Yvonne Rouse and Ronald Rouse, Sr., Individually and as the Personal Representatives of the Estate of Ronald Rouse, deceased vs. South Carolina Board of Education; Darlington School County Board; Hartsville High School; South Carolina High School League; Lake Robinson Rescue Squad; Darlington County Emergency Preparedness; and Darlington County, pages 1-28(Court of Common Pleas, County of Darlington, State of South Carolina, 2014).

23. Swartz EE, Decoster LC, Norkus SA, Cappaert TA. The influence of various factors on high school football helmet face mask removal: a retrospective, cross-sectional analysis. J Athl Train. 2007;42(1):11. [PMID: 17597938]

24. Barrett JR, Tanji JL, Drake C, Fuller D, Kawasaki RI, Fenton RM. High-versus low-top shoes for the prevention of ankle sprains in basketball players: a prospective randomized study. Am J Sports Med. 1993;21(4):582-5. [PMID: 8368420]

25. Craig DI. Medial tibial stress syndrome: evidence-based prevention. J Athl Train. 2008;43(3):316-8. [PMID: 18523568]

26. Grindle M, Games KE, Eberman LE, Kahanov L. Appropriate disinfection techniques for playing surfaces to prevent the transmission of bloodborne pathogens. Int J Athl Ther Train. 2014;19(5):12-5. DOI 10.1123/ijatt.2014-0032.

27. Montgomery K, Ryan TJ, Krause A, Starkey C. Assessment of athletic health care facility surfaces for MRSA in the secondary school setting. J Environ Health. 2010;72(6):8. [PMID: 20104827]

28. Stanforth B, Krause A, Starkey C, Ryan TJ. Prevalence of community-associated methicillin-resistant Staphylococcus aureus in high school wrestling environments. J Environ Health. 2010;72(6):12. [PMID: 20104828]

29. Kerr ZY, Marshall SW, Comstock RD, Casa DJ. Implementing exertional heat illness prevention strategies in US high school football. Med Sci Sports Exerc. 2014;46(1):124-30. [PMID: 24346190]

30. Junge A, Rösch D, Peterson L, Graf-Baumann T, Dvorak J. Prevention of soccer injuries: a prospective intervention study in youth amateur players. Am J Sports Med. 2002;30(5):652-9. [PMID: 12238997]

31. Torres-McGehee TM, Pritchett KL, Zippel D, Minton DM, Cellamare A, Sibilia M. Sports nutrition knowledge among collegiate athletes, coaches, athletic trainers, and strength and conditioning specialists. J Athl Train. 2012;47(2):205- 11. [PMID: 22488287]

32. Baker LB, Heaton LE, Nuccio RP, Stein KW. Dietitian-observed macronutrient intakes of young skill and team-sport athletes: adequacy of pre, during, and postexercise nutrition. Int J Sport Nutr Exerc Metab. 2014;24(2):166-76. [PMID: 24088664]

33. Quelly SB. Childhood obesity prevention: a review of school nurse perceptions and practices. J Spec Pediatr Nurs. 2014;19(3):198-209. [PMID: 24612520]

34. Johnson ST, Norcross MF, Bovbjerg VE, Hoffman MA, Chang E, Koester MC. Sports-related emergency preparedness in Oregon high schools. Sports Health. 2017;9(2):181-4. [PMID: 28129072]

35. Olympia RP, Brady J. Emergency Preparedness in High School-Based Athletics: A Review of the Literature and Recommendations for Sport Health Professionals. Phys Sportsmed. 2013;41(2):15-25. [PMID: 23703513]

36. Valier ARS, Jennings AL, Parsons JT, Vela LI. Benefits of and barriers to using patient-rated outcome measures in athletic training. J Athl Train. 2014;49(5):674-83. [PMID: 25098654]

37. Pryor RR, Casa DJ, Vandermark LW, Stearns RI, Attanasio SM, et al. Athletic training services in public secondary 
schools: a benchmark study. J Athl Train. 2015;50(2):156-162. [PMID: 25689559]

38. Pitney WA. A qualitative examination of professional role commitment among athletic trainers working in the secondary school setting. J Athl Train. 2010;45(2):198-204. [PMID: 202110624]

39. Kerr ZY, Lynall RC, Roos KG, Dalton SL, Djoko A, Dompier TP. Descriptive Epidemiology of Non-Time-Loss Injuries in Collegiate and High School Student-Athletes. J Athl Train. 2017;52(5):446-56. [PMID: 28358221]

40. Norcross MF, Johnson ST, Bovbjerg VE, Koester MC, Hoffman MA. Factors influencing high school coaches' adoption of injury prevention programs. J Sci Med Sport. 2016;19(4):299-304. [PMID: 25866972]

41. Wham Jr GS, Saunders R, Mensch J. Key factors for providing appropriate medical care in secondary school athletics: athletic training services and budget. J Athl Train. 2010;45(1):75-86. [PMID: 20064052] 